\title{
PRZYSIĘGA MAŁŻEŃSKA (ART. 7 § 3 KODEKSU RODZINNEGO I OPIEKUŃCZEGO)
}

\section{WPROWADZENIE}

Nowelizacją z 28 listopada 2014 r. ${ }^{1}$, która weszła w życie 1 marca 2015 r., zmieniono art. 7 k.r.o., który w obecnym brzmieniu zawiera treść oświadczenia o wstapieniu w związek małżeński. Tak oto rota przysięgi małżeńskiej zyskała rangę ustawowego unormowania, w odróżnieniu od poprzedniego stanu prawnego, w którym przepisy prawa regulowały wyłącznie sposób składania oświadczeń, a nie ich brzmienie ${ }^{2}$. Brak ten znajdował jednak uzasadnienie w przeświadczeniu, że w świetle art. $1 \S 1$ k.r.o. istotne jest to, by została przez nupturientów wyrażona wola wstapienia w związek małżeński, niezależnie od użytych przez nich sformułowań (art. 60 k.c.) ${ }^{3}$. W aktualnym stanie prawnym powstaje potrzeba rozważenia skutków dokonanej nowelizacji: oceny charakteru prawnego wprowadzonej formuły i odpowiedzi na pytanie, czy wpływa ona na treść stosunku prawnego małżeństwa w prawie cywilnym.

Pojęcie przysięgi małżeńskiej nie występuje w języku prawnym, za to ma silne zakorzenienie w języku potocznym i - jak zostanie dalej wykazane wykazuje przydatność także w języku prawniczym. Według Słownika języka polskiego „przysięga” jest „uroczystym zobowiązaniem się do wypełniania określonych obowiązków, przestrzegania pewnych zasad; też: tekst tego zobowiązania" " Treść i sposób złożenia przysięgi małżeńskiej wywiera duży wpływ na świadomość nupturientów i dlatego odgrywa znaczącą rolę przy konstruowaniu wewnętrznej relacji w nowo powstałej rodzinie; znaczenia tego aktu można upatrywać również na płaszczyźnie społecznej. Właściwie przebiegająca czynność składania przez nupturientów oświadczeń o wstapieniu w związek małżeński ugruntowuje przeświadczenie o wadze wywoływanych skutków prawnych, ujawnia nową sytuację prawną małżonków i podnosi uroczysty charakter zdarzenia. Pełni również funkcję mobilizującą do prawidłowego wypełniania obowiązków małżeńskich. O ile nupturienci, niedysponujacy szczegółową wiedzą prawnicza, często nie znają całokształtu skutków prawnych

\footnotetext{
${ }^{1}$ Art. 115 Prawa o aktach stanu cywilnego, Dz. U. 2014, poz. 1741 ze zm.

2 Zob. art. 47 dekretu z 8 czerwca 1955 r. - Prawo o aktach stanu cywilnego (Dz. U. 1955, Nr 25, poz. 151 ze zm.); art. 53 ustawy z 29 września 1986 r. - Prawo o aktach stanu cywilnego (Dz. U. 1986, Nr 36, poz. 180) i art. 7 k.r.o. sprzed nowelizacji z 2014 r.

${ }^{3}$ Mezglewski (2014): 30.

${ }^{4}$ Sobol (2010): 798.
} 
wynikających z małżeństwa, to jednak zwykle treść przysięgi małżeńskiej utrwala się w ich świadomości jako wyrażenie istoty zawieranego związku małżeńskiego i woli poddania się jego konsekwencjom. Z uwagi na doniosłe skutki prawne i pozaprawne, jakie wywołuje małżeństwo, chwila jego zawarcia staje się wydarzeniem, postrzeganym jako przełomowe w wielu wymiarach życia człowieka, co wpływa na ukształtowanie treści oświadczenia o zawarciu małżeństwa oraz sposobu jego złożenia. Różnią się więc oświadczenia o zawarciu małżeństwa od treści oświadczeń woli składanych przy zawieraniu umów cywilnoprawnych, których ocena tradycyjnie polega na badaniu prawidłowości wyrażenia essentialia negotii danej czynności prawnej, które nie podlega przecież żadnej ustawowo określonej formule. Różnice te powoduja, że określenie przysięga (bądź ślubowanie) odzwierciedla sposób sformalizowania oświadczeń o zawarciu małżeństwa, podkreśla wagę i uroczystość dokonywanego za jej pomoca aktu i odpowiada praktyce języka potocznego, stąd nie ma przeszkód, by posługiwać się nim również w toku rozważań prawniczych. W dalszych wywodach pojęcie przysięgi małżeńskiej będzie więc używane do oznaczenia formuły (roty) oświadczeń składanych przez nupturientów podczas aktu zawarcia związku małżeńskiego.

\section{PRZYSIĘGA MAŁŻEŃSKA W FORMIE WYZNANIOWEJ ZAWARCIA MAŁŻEŃSTWA}

$\mathrm{Na}$ wstępie trzeba odnotować, że występują istotne różnice pomiędzy treścią składanych przez nupturientów oświadczeń w przypadku zawarcia małżeństwa w formie świeckiej oraz w formie wyznaniowej. Artykuł 7 k.r.o., regulujący rotę przysięgi małżeńskiej, ma bowiem zastosowanie wyłącznie w tzw. trybie świeckim zawarcia małżeństwa. Natomiast w przypadku zawierania małżeństwa przed duchownym nupturienci nie składaja formalnych oświadczeń o zawarciu małżeństwa o skutkach cywilnych, które przybierałyby postać ślubowania. W stosowanych w praktyce formularzach urzędowych nie przewiduje się roty jakichkolwiek oświadczeń w tym przedmiocie $^{5}$, a jedynie potwierdzenie przez duchownego, że nupturienci zawarli małżeństwo podlegające prawu wewnętrznemu kościoła lub związku wyznaniowego, zgodnie oświadczając wolę jednoczesnego zawarcia małżeństwa podlegającego prawu polskiemu ${ }^{6}$. Przebieg ceremonii zawarcia małżeństwa $\mathrm{w}$ formie wyznaniowej, w tym treść składanych w jej toku oświadczeń, podlega prawu wewnętrznemu poszczególnych kościołów i związków wyznaniowych, co oznacza, że nie istnieje jednolita formuła dokonania tego aktu. W doktrynie spotyka się niekiedy stanowisko, że do powstania stosunku prawnego małżeństwa niezbędne jest złożenie przez nupturientów dwóch oświadczeń: oświadczenia o zawarciu małżeństwa wyznaniowego według

\footnotetext{
5 Mezglewski (2007): 128-137.

${ }^{6}$ Zob. Gajda (2000): 179-180, 185-186.
} 
roty przewidzianej przez prawo wewnętrzne danego związku wyznaniowego oraz niesformalizowanego oświadczenia woli o jednoczesnym zawarciu małżeństwa cywilnego ${ }^{7}$. Uwypukla się tu okoliczność, że przed duchownym dochodzi do złożenia przez nupturientów oświadczenia, że wstępują w związek małżeński ${ }^{8}$. Stanowisko to, w generalnym założeniu trafne, wymaga jednak doprecyzowania. Otóż warto zauważyć, że nie we wszystkich związkach wyznaniowych praktykowane jest składanie przez nupturientów przysięgi małżeńskiej według panującego powszechnie wyobrażenia. Za przykład niech posłuży Związek Gmin Wyznaniowych Żydowskich, w którym ceremonia zaślubin obejmuje dwa następujące po sobie etapy: zaręczyny (kiddushin) i sfinalizowanie ślubu (nisu’in). Podczas obrzędu zaręczyn oświadczenie składa tylko mężczyzna i ma ono treść: „Tą obrączką poślubiam cię wedle prawa Mojżeszowego i Izraela”. Kolejną czynnością jest odczytanie kontraktu małżeńskiego (ketuba), a podczas ceremonii ślubnej obecni odmawiają siedem błogosławieństw ${ }^{9}$. Brak tutaj zdarzenia polegającego na złożeniu przysięgi według określonej roty. Należy zauważyć, że art. 1 § 2 k.r.o., wyliczający przesłanki konieczne zawarcia małżeństwa przed duchownym ze skutkami zawarcia małżeństwa cywilnego, nie wspomina o złożeniu przed duchownym oświadczenia o wstapieniu w związek małżeński, lecz o zawieraniu związku małżeńskiego podlegającego prawu wewnętrznemu kościoła albo innego związku wyznaniowego. Złożenie roty przysięgi małżeńskiej nie jest zatem niezbędne, by uznać, że nastapiło zawarcie małżeństwa zgodnie z wyznaniowym prawem wewnętrznym ${ }^{10}$. Jeżeli więc prawo wewnętrzne kościoła nie przewiduje wypowiedzenia takiej formuły przez nupturientów, przesłanka z art. $1 \S 2$ k.r.o. jest spełniona, gdy dopełniono, zgodnie z prawem wewnętrznym, właściwych czynności ceremoniału zawierania małżeństwa. Jednakże w typowym przypadku złożenie przysięgi małżeńskiej stanowi centralny element ceremonii zawierania małżeństwa przed duchownym.

Treść formuł oświadczeń nupturientów o wstapieniu w związek małżeński stosowanych w poszczególnych kościołach albo związkach wyznaniowych, wykazuje istotne różnice. W niektórych kościołach, poza formułą ustalona prawem wewnętrznym, dopuszcza się możliwość ułożenia jej treści przez nupturientów w porozumieniu z duchownym (np. w Kościele Adwentystów Dnia Siódmego ${ }^{11}$ ). Z kolei mając na uwadze postać przysięgi małżeńskiej, można wyróżnić teksty mające formę jednolitej wypowiedzi każdego z nupturientów

${ }^{7}$ Mezglewski (2011): 17-18; Strzebinczyk (2016): 61. Zob. też Mezglewski, Tunia (2007): 110. W doktrynie zgłasza się postulaty sformalizowania oświadczenia o jednoczesnym zawarciu małżeństwa cywilnego - Dudziak (1994): 115.

8 Zakrzewski (2011): 33-34.

9 Szerzej na temat porównania treści przysiąg małżeńskich w poszczególnych kościołach i związkach wyznaniowych - zob. Sylwestrzak (2011): 209-218.

10 Należy przychylić się nadto do stanowiska, że ważność małżeństwa wyznaniowego nie jest przesłanką konieczną z art. $1 \S 2$ k.r.o. Zob. Gajda (2014): 128-129. Związek stosunku prawnego małżeństwa cywilnego ze stosunkiem małżeństwa wyznaniowego widoczny jest tylko w momencie ich zawarcia - tak Mączyński (2005): 82. Por. Mezglewski (2003): 827.

11 Zob. Seventh-day Adventist Miniser's Manual: rozdz. 42. 
(np. w Kościele katolickim ${ }^{12}$ ) oraz oświadczenia będące odpowiedziami na pytania zadawane przez duchownego (np. w Kościele prawosławnym ${ }^{13}$ ). Warto również zauważyć, że nie zawsze oświadczenia składane przez kobietę i mężczyznę są tożsame co do treści - przykładowo, w Kościele greckokatolickim kobieta dodatkowo zobowiązuje się do posłuszeństwa wobec męża, a w Kościele zielonoświątkowym kobieta ślubuje mężowi uległość.

Ponieważ prawo cywilne nie ingeruje w treść składanych przed duchownym przysiag, następuje skutek polegający na tym, że pary małżeńskie, które zawarły małżeństwo o skutkach cywilnych w różnych kościołach, składały ślubowania o różnej treści, odmiennej również od przysięgi, którą złożyły pary zawierające małżeństwo przed kierownikiem urzędu stanu cywilnego (USC); występuja także pary małżeńskie, które nie składały ślubowania, ponieważ ceremonia religijna zawarcia małżeństwa nie obejmowała takiego aktu. Czy wobec tego treść art. $7 \S 3$ k.r.o. może odgrywać jakiekolwiek znaczenie dla definicji i skutków prawnych małżeństwa w prawie cywilnym? Zagadnienie to będzie przedmiotem dalszych rozważań.

\section{CHARAKTER PRAWNY FORMUŁY PRZYSIĘGI MALŻEŃSKIEJ SKŁADANEJ W FORMIE ŚWIECKIEJ ZAWARCIA MAŁŻEŃSTWA}

W myśl art. $7 \S 3$ k.r.o. treść oświadczenia o wstapieniu w związek małżeński brzmi: „Świadomy/Świadoma praw i obowiązkow wynikajacych z zawarcia małżeństwa uroczyście oświadczam, że wstępuję w związek małżeński z (imię i nazwisko drugiej z osób wstępujących w związek małżeński) i przyrzekam, że uczynię wszystko, aby nasze małżeństwo było zgodne, szczęśliwe i trwałe”. Nowelizacja k.r.o. zmieniła nieznacznie stosowaną wcześniej w USC formułę ${ }^{14}$, podnosząc ją jednocześnie do rangi ustawowej, wobec czego nie jest już odtąd możliwe negocjowanie zmiany jej treści przez nupturientów.

W pierwszej kolejności trzeba określić charakter prawny przytoczonego oświadczenia. Pośród przesłanek koniecznych zawarcia małżeństwa w formie świeckiej art. 1 § 1 k.r.o. wymienia złożenie przez mężczyznę i kobietę oświadczenia, że wstępują ze sobą w związek małżeński. Z kolei art. 7 k.r.o., formu-

12 „Ja X, biorę ciebie, Y, za żonę i ślubuję ci miłość, wierność i uczciwość małżeńską oraz że cię nie opuszczę aż do śmierci. Tak mi dopomóż, Panie Boże Wszechmogący, w Trójcy jedyny, i wszyscy Święci”. Zob. Obrzędy sakramentu małżeństwa dostosowane do zwyczajów diecezji polskich, wydane przez Konferencję Episkopatu Polski w 1974 r.

${ }^{13}$ Dialog przed obrzędem koronowania - Duchowny: „Czy masz dobrą i nieprzymuszoną wolę oraz mocne postanowienie pojąc sobie za żonę tę oto X, którą tu przy sobie widzisz?”. Nupturient: „Mam, czcigodny ojcze”. Duchowny: „Czy nie obiecałeś małżeństwa innej kobiecie?”. Nupturient: „Nie obiecałem, czcigodny ojcze”. Oświadczenia składane są w języku ukraińskim. Zob. Bondaruk (1987): 87.

${ }^{14}$ We wcześniejszej, stosowanej w praktyce formule była mowa o prawach i obowiązkach wynikających z założenia rodziny. Obowiązująca rota przysięgi łączy skutki prawne z zawarciem małżeństwa, co jest w świetle art. 23 k.r.o. trafniejsze - rodzina powstaje bowiem przez zawarcie małżeństwa, czyli jej powstanie jest jednym ze skutków małżeństwa, a nie odwrotnie. 
łujący treść przysięgi małżeńskiej, nazywa ją „oświadczeniem o wstapieniu w związek małżeński”. Czy można stąd wywodzić wniosek, że w art. 7 k.r.o. mowa jest o tym samym oświadczeniu, które art. 1 § 1 k.r.o. lokuje pośród przesłanek konstytutywnych zawarcia małżeństwa, a w konsekwencji - że treść ślubowania objęta jest statusem przesłanki koniecznej zawarcia małżeństwa? Odpowiedź na to pytanie wymaga analizy treści przysięgi małżeńskiej, w której można wyróżnić szereg zróżnicowanych elementów. Mianowicie, oprócz wyrażenia woli wstapienia w związek małżeński z drugim z nupturientów, formuła zawiera:

- oświadczenie o świadomości praw i obowiązków wynikających z zawarcia małżeństwa;

- podkreślenie uroczystości dokonywanego aktu (słowo: „uroczyście”);

- przyrzeczenie dołożenia najwyższej staranności (,przyrzekam, że uczynię wszystko") dla osiagnięcia skutku w postaci zgodnego, szczęśliwego i trwałego związku.

Gdyby podczas składania przysięgi którykolwiek z nupturientów zmodyfikował jej treść, może powstać wątpliwość, czy doszło do złożenia oświadczenia w rozumieniu art. $1 \S 1$ k.r.o. Modyfikacja taka, z uwagi na duże emocje towarzyszące zwykle aktowi zawarcia małżeństwa, może być wynikiem niezamierzonej pomyłki, ale może też mieć charakter celowej ingerencji w treść formuły. Poza tym jeżeli formuły wypowiedziane przez każdą ze stron różniłyby się od siebie, powstałaby wątpliwość, czy mamy wówczas do czynienia ze złożeniem zgodnych oświadczeń (o zgodności oświadczeń stanowi art. 7 § 4 k.r.o.). Gdyby przyjąć koncepcję, że oświadczeniem, o którym mowa w art. $1 \S 1$ k.r.o., będącym przesłanką konieczną zawarcia małżeństwa, jest oświadczenie o treści wskazanej w art. 7 § 3 k.r.o., trzeba byłoby uznać, że cała treść przysięgi małżeńskiej stanowi conditio iuris zawarcia małżeństwa, a więc najmniejsze nawet uchybienie w jej wyrażeniu musiałoby powodować, że nupturient oświadczenia nie złożył. Stanowisko takie obarczone byłoby jednak nadmiernym formalizmem i pociagałoby za sobą zbyt wiele negatywnych konsekwencji ${ }^{15} \mathrm{w}$ porównaniu z wartościa, na straży której miałoby stać, a która jest zapewnienie prawidłowości wyrażenia woli wstapienia w związek małżeński, dlatego nie znajduje aprobaty w doktrynie. Prezentowany jest natomiast trafny pogląd, według którego oświadczenia małżonków o wstapieniu w związek małżeński mogłyby mieć inną postać werbalną niż wskazana w k.r.o. ${ }^{16}$ Właściwe rozumienie art. 7 § 3 k.r.o. musi upatrywać przesłanki koniecznej zawarcia małżeństwa tylko we fragmencie przytoczonej w nim formuły: „oświadczam, że wstępuję w związek małżeński z (imię i nazwisko)", traktowanym jako konieczny sens, który powinien zostać wyrażony podczas aktu zawarcia małżeństwa (art. 60 k.c.) $)^{17}$, a nie jako obligatoryjna formuła, która musi zostać wypowiedziana bez uchy-

15 Zwłaszcza w postaci możliwości ustalenia nieistnienia małżeństwa z powodu „błahej” pomyłki przy składaniu przysięgi małżeńskiej.

16 Domański (2017): 24-25; Nazar (2016): 196.

17 Sporne jest, czy przepisy dotyczące oświadczenia woli mogą być stosowane wprost do oświadczenia o zawarciu małżeństwa, ponieważ część autorów nie kwalifikuje tego oświadczenia jako oświadczenia woli - zob. Domański (2017): 88. 
bień. Przykładowo, jeżeli nupturient, zamiast użyć sformułowania „wstępuję w związek małżeński”, oświadczy innymi słowami równoznaczny sens: „oświadczam, że zawieram małżeństwo z (imię i nazwisko)” albo na przykład użyje formy zdrobniałej imienia bądź pseudonimu, niebudzącego wątpliwości co do tożsamości drugiej strony, nie sposób byłoby twierdzić, że nie doszło do skutecznego złożenia oświadczenia o wstapieniu w związek małżeński. Pozostałe elementy przysięgi małżeńskiej (nazwijmy je, na potrzeby dalszych rozważań, elementami dodatkowymi) pełnia wobec podstawowego oświadczenia funkcję uzupełniającą. Jednakże ze względu na powiązanie treści wszystkich elementów przysięgi, tworzących przecież spójną całość, uchybienia dotyczące elementów dodatkowych mogą mieć niekiedy wpływ na ocenę, czy doszło do złożenia oświadczenia o wstapieniu w związek małżeński. Byłoby tak wtedy, gdyby modyfikacje formuły ślubowania prowadziły w istocie do zakwestionowania skutków dokonywanego aktu. Przykładowo zanegowanie przez nupturienta dążenia do trwałości małżeństwa, dodanie niedopuszczalnego warunku bądź terminu ${ }^{18}$ czy wyłączenie niepodlegających dyspozycji stron praw i obowiązków małżeńskich (np. wspólnego pożycia czy wierności) mogłoby prowadzić do wniosku, że nupturient ten w rzeczywistości małżeństwa zawierać nie chce, a zatem oświadczenie przez niego złożone nie może być uznane za skuteczne, skoro nie wyraził woli zwarcia małżeństwa. Kierownik USC, realizując zasadę prawdy obiektywnej, nie może wówczas sporządzić aktu małżeństwa, ponieważ nie doszło do złożenia zgodnych oświadczeń o wstapieniu w związek małżeński ${ }^{19}$. Z kolei takie modyfikacje formuły przysięgi małżeńskiej, które nie negują istoty małżeństwa, pozostają bez znaczenia dla oceny prawidłowości zawarcia małżeństwa. Jako przykład niech posłuży pominięcie słowa „uroczyście”, przekształcenie słowa „przyrzekam” w „przysięgam” bądź dodanie formuły odwołania do Boga (np. „w obliczu Boga” lub „Tak mi dopomóż Bóg"). W takim przypadku wypowiedzenie przez każdego z nupturientów odmiennej formuły nie stanowi przeszkody do uznania, że doszło do złożenia przez nich zgodnych oświadczeń ${ }^{20}$.

W konkluzji trzeba stwierdzić, że oświadczenie o zawarciu małżeństwa będące konieczną przesłanką jego zawarcia (art. $1 \S 1$ k.r.o.) zostało przez ustawodawcę w art. $7 \S 3$ k.r.o. „odziane” w pewną szerszą formułę, która nie stanowi jednak samoistnej przesłanki konstytutywnej małżeństwa. Uchybienia przy jej wypowiadaniu nie mogą więc być oceniane jako brak takiej przesłanki (a w konsekwencji - matrimonium non existens) ${ }^{21}$, o ile nie neguja ustalenia, że nupturient wyraził wolę zawarcia małżeństwa z druga stroną. Dochodzi więc w art. $7 \S 3$ k.r.o. do swoistego zbiegu przesłanki koniecznej zawarcia małżeństwa (złożenie oświadczenia o zawarciu mał-

18 Tak np. Andrzejewski (2004): 37.

19 Sytuacjom takim w dużym stopniu przeciwdziała wcześniejszy etap ceremonii zawierania związku małżeńskiego, w którym kierownik USC zapytuje nupturientów, czy zamierzają zawrzeć ze sobą małżeństwo (art. 7 § 2 k.r.o.). Szerzej o roli kierownika USC przy zawieraniu małżeństwa Domański (2013): 54-57.

${ }^{20}$ O zgodności oświadczeń jako zgodności ich treści - zob. Smyczyński (2009): 29.

21 Szerzej Łukasiewicz (2017): 115-130. 
żeństwa) z przesłanką porządkową (formuła przysięgi małżeńskiej), kiedy to tylko niektóre naruszenia formuły będą wywierać negatywny wpływ na zawarcie małżeństwa.

\section{SKUTKI PRAWNE USTAWOWEGO UREGULOWANIA FORMUŁY PRZYSIĘGI MAŁŻEŃSKIEJ}

Wprowadzenie do k.r.o. formuły przysięgi małżeńskiej nasuwa pytanie, czy poza jej podstawowym skutkiem w postaci zawarcia małżeństwa można z jej treści wywodzić inne jeszcze skutki prawne. A zatem czy przysięga małżeńska odrywa rolę wyłącznie podczas kreowania stosunku prawnego małżeństwa, czy też dodatkowo wpływa na kształtowanie jego treści?

Trzeba zauważyć, że początek formuły z art. $7 \S 3$ k.r.o. spina niejako klamrą wszystkie skutki prawne małżeństwa przyjmujące kategorię praw i obowiązków, obejmując je złożonym oświadczeniem. Nie wnosi więc wartości dodanej do treści stosunku prawnego małżeństwa. Dopiero końcowy fragment formuły, słowami „przyrzekam, że uczynię wszystko”, wyraża podjęcie obowiązku odpowiadającego w swej postaci zobowiązaniu starannego działania, polegającego na dążeniu do osiagnięcia stanu opisanego jako zgodne, szczęśliwe i trwałe małżeństwo. Fragment ten można odczytywać na dwa sposoby. Po pierwsze, zakładając, że nie stanowi on o żadnych dodatkowych skutkach prawnych małżeństwa, ponieważ jest on deklaracją starannego wypełniania obowiązków, o których była mowa na początku oświadczenia. W tym ujęciu początkowy fragment oświadczenia dotyczy świadomości skutków prawnych małżeństwa, a końcowy - wyrażenia woli ich prawidłowej realizacji. Małżeństwo zgodne, szczęśliwe i trwałe to stan, który można osiagnąć dzięki starannemu wypełnianiu obowiązków małżeńskich, a nie treść dodatkowego obowiązku wynikającego ze składanego oświadczenia. Z kolei według drugiej koncepcji końcowa część oświadczenia pełni nadto jeszcze jedną rolę: konstytuuje dodatkowe powinności małżonków, za czym może przemawiać fakt, że mowa tu o stanie, który wyraźnie nie wynika z dalszych przepisów k.r.o. (zwłaszcza szczęśliwość i zgodność). Gdyby przyjać taki kierunek wykładni, powstaje pytanie - czy obowiązki te maja charakter prawny?

Poszukiwanie odpowiedzi na tak postawione pytanie prowadzi do wyboru pomiędzy trzema koncepcjami. Według pierwszej, upatrującej w dodatkowych elementach przysięgi małżeńskiej źródła obowiązków prawnych, art. 7 $\S 3$ k.r.o. uzupełnia prawa i obowiązki unormowane w dalszych przepisach k.r.o., a ich naruszenie jest obarczone tzw. sankcja rodzinnoprawna, polegającą na możliwości przypisania winy rozkładu pożycia w razie ewentualnego orzeczenia rozwodu bądź separacji ${ }^{22}$. Na rzecz tego stanowiska może przemawiać założenie, że ustawodawca nie zmierza, co do zasady, do tworzenia lex imperfecta ani też do nadawania „szaty prawnej” regułom obyczajowym, bez

${ }^{22}$ Szerzej o sankcji rodzinnoprawnej zob. Sokołowski (2013): 15. 
zamiaru podniesienia ich do rangi normy prawnej. Okoliczność, że nie wszystkie pary małżeńskie tę przysięgę składały, nie ma znaczenia, ponieważ formułę tę należałoby postrzegać szerzej - jako element skutków prawnych każdego małżeństwa cywilnego. Druga koncepcja polegałaby na zanegowaniu samoistnej roli formuły, która ma służyć wyłącznie zawarciu małżeństwa, a nie kształtowaniu jego skutków prawnych. Jej dodatkowe elementy, w tym końcowe przyrzeczenie, spełniają szereg ważnych funkcji psychologiczno-społecznych, nie będąc jednak źródłem żadnych „nowych” praw i obowiązków. Argumentu dla uzasadnienia takiego zapatrywania dostarcza fakt, że przysięgę tę składają tylko nupturienci zawierający małżeństwo w formie świeckiej, wobec czego można twierdzić, że nie byłoby dopuszczalne ani różnicowanie skutków prawnych małżeństwa w zależności od formy jego zawarcia ${ }^{23}$, ani rozciaganie konsekwencji zawartych w treści oświadczenia na małżonków, którzy go nie składali. Nie pozostaje zatem nic innego, jak uznanie, że treści w niej zawarte, gdy chodzi o skutki prawne małżeństwa, maja charakter prawnie obojętny i wyrażają jedynie oczekiwania uzasadnione etycznie i obyczajowo.

Możliwa jest jednak także i trzecia koncepcja, pośrednia, według której przyrzeczenie zawarte w końcowej części oświadczenia, nie może być wprawdzie źródłem odrębnych skutków prawnych, ale też nie powinno zostać pominięte przy wykładni przepisów o prawach i obowiązkach małżeńskich. W tym ujęciu unormowanie przez ustawodawcę określonej treści przysięgi małżeńskiej powinno być postrzegane jako ujawnienie cech modelu prawidłowego funkcjonowania małżeństwa (modelu wzorcowego). W treści oświadczenia składanego w formie świeckiej (w odróżnieniu od niektórych przysiąg składanych w formie wyznaniowej ${ }^{24}$ ) z natury rzeczy nie mogłyby się przecież znaleźć treści sprzeczne z unormowaniami k.r.o. na temat skutków prawnych małżeństwa. Analizowane sformułowania trzeba zatem uznać za afirmujace realizację praw i obowiązków małżeńskich - i to w sposób ustawowo określony, a więc odpowiadający „wyobrażeniu” ustawodawcy o prawidłowej relacji małżonków. Ta właśnie, ostatnia koncepcja wydaje się najbardziej przekonująca. Ucieleśnioną w treści przysięgi małżeńskiej intencję ustawodawcy można zatem wykorzystać w toku interpretacji przepisów o prawach i obowiązkach małżonków, niezależnie od tego, w jakiej formie zawierane było małżeństwo. Przykładowo, wynikający z art. 24 k.r.o. obowiązek wspólnego rozstrzygania o istotnych sprawach rodziny, interpretowany $\mathrm{w}$ świetle wyrażonego $\mathrm{w}$ art. 7 $\S 3$ k.r.o. przeświadczenia ustawodawcy o pożądanym dążeniu małżonków do zgodności, może przekładać się na negatywną ocenę bezkompromisowej postawy jednego z małżonków, wymagającego stałych ustępstw, bądź też postawy polegajaccej na celowym antagonizowaniu stanowisk - jako zachowań naruszających obowiązki małżeńskie. Wyrazu dezaprobaty ustawodawcy dla takiego postępowania można doszukiwać się właśnie między innymi w treści przy-

${ }^{23}$ Szerzej o niedopuszczalności naruszania zasady równości małżeństw: Pęczyk-Tofel, Tofel (2007): 69-70.

${ }^{24}$ Przykładowo, ślubowanie przez żonę posłuszeństwa mężowi w Kościele zielonoświątkowym jest sprzeczne z zasadą prawa rodzinnego równouprawnienia małżonków (art. 23 k.r.o.). 
sięgi małżeńskiej. Innym przykładem może być obowiązek wspólnego pożycia (art. 23 k.r.o.), który w powiązaniu ze wskazaną w art. 7 § 3 k.r.o. powinnościa dążenia do osiagania szczęśliwości w małżeństwie może stać się podstawą do przypisania winy rozkładu pożycia temu z małżonków, który swoim przykrym, trudnym do zniesienia zachowaniem do takiego stanu doprowadził.

$$
* * *
$$

W podsumowaniu trzeba stwierdzić, że ewentualne uchybienia podczas składania przysięgi małżeńskiej, które polegają na zmianie jej treści, lecz nie negują woli zawarcia małżeństwa, nie wywołują negatywnych skutków. Jest tak dlatego, że wypowiedzenie przez nupturientów roty, o której mowa w art. 7 $\S 3$ k.r.o., należy w istocie do przesłanek porządkowych zawarcia małżeństwa, natomiast przesłanką konieczną zawarcia małżeństwa jest - w myśl art. 1 $\S 1$ k.r.o. - złożenie oświadczeń o wstapieniu w związek małżeński, przy czym ten ostatni przepis nie łączy skutków prawnych z użytym przez nupturientów sformułowaniem, lecz raczej z jego sensem.

Wartością dodaną omawianej nowelizacji jest możliwość sięgnięcia do treści przysięgi małżeńskiej przy wykładni przepisów dotyczących praw i obowiązków małżeńskich. Treść tej formuły może bowiem okazać się pomocna przy konstruowaniu modelu prawidłowego postępowania małżonków i ta droga, pośrednio, wywoływać konsekwencje w praktyce stosowania prawa. $\mathrm{Z}$ art. $7 \S 3$ k.r.o. nie można natomiast wywodzić innych niż przewidziane w dalszych unormowaniach Kodeksu praw i obowiązków małżeńskich.

Anna Sylwestrzak

Uniwersytet Gdański

anna.sylwestrzak@prawo.ug.edu.pl

https: / /orcid.org/0000-0001-8346-1926

Andrzejewski, M. (2004). Prawo rodzinne i opiekuńcze. Warszawa: C.H. Beck.

Bondaruk, K. (1987). Nauka o nabożeństwach prawosławnych. Białystok: Prawosławna Diecezja Białostocko-Gdańska.

Domański, M. (2013). Względne zakazy małżeńskie. Warszawa: Wolters Kluwer.

Domański, M. (2017). Komentarz do art. 1 k.r.o., [w:] K. Osajda (red.), Kodeks rodzinny i opiekuńczy. Komentarz. Warszawa: C.H. Beck: 3-39.

Dudziak, J. (1994). Zharmonizowanie kanonicznego prawa małżeńskiego i polskiego prawa rodzinnego w Konkordacie, [w:] J. Dyduch (red.), Rola i znaczenie Konkordatu 1993 r. Kraków: Wydawnictwo „Czuwajmy”.

Gajda, J. (2014). Zawarcie małżeństwa, [w:] T. Smyczyński (red.), System prawa prywatnego. Tom 11: Prawo rodzinne i opiekuńcze. Warszawa: C.H. Beck: 69-150.

Gajda, P.M. (2000). Prawo małżeńskie Kościoła Katolickieg. Tarnów: Wydawnictwo Biblos.

Łukasiewicz, J. (2017). Nieistnienie małżeństwa - rozważania ogólne na podstawie wybranych poglądów, [w:] J. Łukasiewicz, A. Arkuszewska, A. Kościółek (red.), Wokół problematyki małżeństwa w aspekcie materialnym i procesowym. Toruń: Wydawnictwo Adam Marszałek: $115-130$.

Mączyński, A. (2005). Oświadczenia małżonków jako element zawarcia małżeństwa w formie konkordatowej, [w:] P. Kasprzyk (red.), Prawo rodzinne w Polsce i w Europie. Lublin: Towarzystwo Naukowe KUL: 69-84. 
Mezglewski, A. (2003). Jedno małżeństwo czy dwa? Rzecz o istocie małżeństwa konkordatowego. Monitor Prawniczy 18: 820-827.

Mezglewski, A. (2007). Urzędowy formularz zaświadczenia stanowiącego podstawę rejestracji małżeństwa zawieranego w formie wyznaniowej, [w:] H. Cioch, P. Kasprzyk (red.), Z zagadnień prawa rodzinnego i rejestracji stanu cywilnego. Lublin: Wydawnictwo KUL: 128-135.

Mezglewski, A. (2011). Katalog przesłanek koniecznych zawarcia małżeństwa cywilnego w formie wyznaniowej, [w:] A. Tunia (red.), Przesłanki konieczne zawarcia małżeństwa. Próba systematyzacji zagadnienia $\mathrm{w}$ aspekcie wymogów formy religijnej. Lublin: Wydawnictwo KUL: $11-21$.

Mezglewski, A. (2014). Konstrukcja oświadczenia woli o zawarciu małżeństwa, [w:] T. Rakoczy (red.), Małżeństwo jako zawarty związek mężczyzny i kobiety. Lublin: Wydawnictwo KUL: $29-40$.

Mezglewski, A., Tunia, A. (2007). Wyznaniowa forma zawarcia małżeństwa cywilnego. Warszawa: C.H. Beck.

Nazar, M. (2016). Małżeństwo, [w:] J. Ignatowicz, M. Nazar, Prawo rodzinne. Warszawa: Wolters Kluwer: 192-206.

Pęczyk-Tofel, A., Tofel, M. (2007). Przesłanki zawarcia małżeństwa konkordatowego w świetle przepisów Konstytucji. Przegląd Sądowy 17(7/8): 58-70.

Smyczyński, T. (2009). Prawo rodzinne i opiekuńcze. Warszawa: C.H. Beck.

Sobol, E. (2010). Słownik języka polskiego. Warszawa: Wydawnictwo Naukowe PWN.

Sokołowski, T. (2013). Prawo rodzinne. Zarys wykładu. Poznań: Ars boni et aequi.

Strzebinczyk, J. (2016). Prawo rodzinne. Warszawa: Wolters Kluwer.

Sylwestrzak, A. (2011). Oświadczenia o zawarciu małżeństwa w prawie wewnętrznym poszczególnych zwiąków wyznaniowych, [w:] A. Tunia (red.), Przesłanki konieczne zawarcia małżeństwa. Próba systematyzacji zagadnienia w aspekcie wymogów formy religijnej. Lublin: Wydawnictwo KUL: 209-218.

Zakrzewski, P. (2011). Model zawarcia małżeństwa w prawie polskim a oświadczenia mężczyzny i kobiety jednoczesnego zawarcia małżeństwa w trybie art. $1 \S 2$ k.r.o., [w:] A. Tunia (red.), Przesłanki konieczne zawarcia małżeństwa. Próba systematyzacji zagadnienia w aspekcie wymogów formy religijnej. Lublin: Wydawnictwo KUL: 23-40.

\section{THE MARRIAGE VOW \\ (ARTICLE 7 PARA. 3 OF THE FAMILY AND GUARDIANSHIP CODE)}

\section{Summary}

The amendment to the Family and Guardianship Code of 2014, introducing the wording of the declaration of entering into marriage, deserves a positive assessment. Due to the importance of the marriage vow, it was right to assign it the rank of a legislative act. At the same time, it should be emphasized that no changes have been made regarding the preconditions required for entering into marriage because the constitutive element of entering into marriage is, as previously, expressing the will to enter into marriage, and not uttering a specific formula of words. Any incorrect uttering of the words does not have a negative effect on the act of entering into the marriage, as long as there is no doubt that, in spite of the incorrect uttering of the words, the will to enter into marriage has been expressed. Therefore, the wording of the marriage vow should be considered as an organizational precondition for entering into marriage. Its content may be deemed helpful during the interpretation of the provisions regarding the rights and obligations of spouses, and therefore, indirectly, may affect the application of law in practice.

Keywords: the marriage vow; entering into marriage 